\title{
Non-Performing Loans and Systemic Risk: Empirical Evidence to Tunisia and Morocco
}

\author{
Saoussen Ouhibi* \\ University of Sfax , Tunisia \\ saoussenouhibi@yahoo.fr \\ Algia Hammami** \\ University of Sfax, Tunisia \\ hammamialgia@yahoo.fr \\ Salma Ezzeddine** \\ University of Sfax , Tunisia \\ salmaezzeddine@gmail.com
}

\begin{abstract}
This study investigates the determinant factors of systemic risk in Tunisia and Morocco. The comparative analysis showed that Inflation, domestic credit, gross capital formation, GDP, unemployment rate are significant with nonperforming loans (source of systemic risk), in Tunisia. However, in Morocco, only the exchange rate and GDP are significant. This study used time series data of NPLs ratio and nine macroeconomic variables over the period of 1990-2014. Moreover, OLS was used to test the explanatory power of macroeconomic variables as determinants of NPLs.
\end{abstract}

Keywords: Nonperforming loans, Systemic Risk, macroeconomics variables, Tunisia, Morocco.

JEL Classification : $G 21, E 44, C 51$.

\section{INTRODUCTION}

The research on the topic of systemic risk began in the 1990s mainly because of financial instability periods in that decade (Bartholomew 2000). The systemic risk in the banking system has attracted the attention of financial researchers. According to the Group of Ten (2001), "Systemic financial risk is the risk when an event triggers a loss of economic value or confidence in, and attendant increases in uncertainty about, a substantial portion of the financial system that is serious enough to quite probably have significant adverse effects on the real economy ». Indeed, the recent debate on systemic risk and financial stability in the banking system mainly, tries to know the factors responsible for non performing loans.

Nonperforming loans are the main source of the spread of systemic risk in the banking and financial sector. An increase of non-performing loans can be determined by a number of factors, including an increase in short-term interest rates, real interest rates, unemployment rates, inflation and exports.... According to Paul S (2012), a major source of risk for the southern Mediterranean countries is the changes in the value of exports and the increase of the price level. Indeed, the macroeconomic instability on the Bank's balance sheet is also a major source of systemic risk to the banking sector. Common exposure to macroeconomic risk factors across banks is a source of systemic risk that influences the quality of a loan portfolio, which can be expressed as the ratio of non-performing loans to total gross loans. An increasing ratio may be a signal of deterioration in the banking sector results. In theory, we would expect the risk of credit expansion and the non-performing loans to a total loan (NPL) ratio to be procyclical within an economic cycle (Schinasi 2005).

The deterioration of the quality of the loan portfolio is the main cause of problems in the banking systems, and asset qualities are often associated with the presence of bankruptcy risk and financial crisis in both developed and developing countries. Nonperforming loans are among the main causes of economic stagnation problems (Nkusu, 2011). The presence of these loans causes a problem in the financial sector and increases the possibility of difficulty and unpredictability in the company. 
The negative effects of the global financial crisis on the southern Mediterranean countries helped to demonstrate that the external funding sources can induce macroeconomic instability contexts to the difficulty of combining the autonomy of the monetary policy and the stability of the exchange rate, hence the risk of financial system vulnerability of these economies. Tunisia and Morocco are two countries of the Southern Mediterranean and there are economic relations and cooperation between the two countries, we decided to compare these two economies in the context of the banking sector. Therefore, the main aim of the current study is to analyze the relationship between the ratio of nonperforming loans (NPL) and the macroeconomic variables as a source of systemic risk to assess the vulnerability of the banking sector. The remaining part of this paper is organized as follows. Section two describes the nonperforming loans and systemic risk in the banking sector of Tunisia and Morocco. Third section discusses the empirical literature overview. Section four presents the empirical analysis and includes the data and methodology, data, results and discussion, and the final section presents the conclusion.

\section{Non-Performing Loans and Systemic Risk in the Banking Sector of Tunisia AND MOROCCO}

The nonperforming loans (NPLs) expressed as a percentage of GDP, are used for the assessment of systemic risk. This study analyzes the relationship between systemic risk and non performing loans in order to assess the banking sector in Tunisia and Morocco.

\subsection{In Tunisia}

The percentage of non-performing loans in Tunisia reflects the health of the banking system. A higher percentage of such loans show that banks have difficulty in setting the interest rates of their credits. This may lead to less profit for the banks in Tunisia and, possibly, the bank closures. The rising of nonperforming loans and concentrated exposures need to be monitored by macroprudential surveillance. The authority efforts to strengthen the macroprudential framework by implementing the macroprudential tools and the enhancing systemic risk surveillance are welcomed.

\section{PNP}

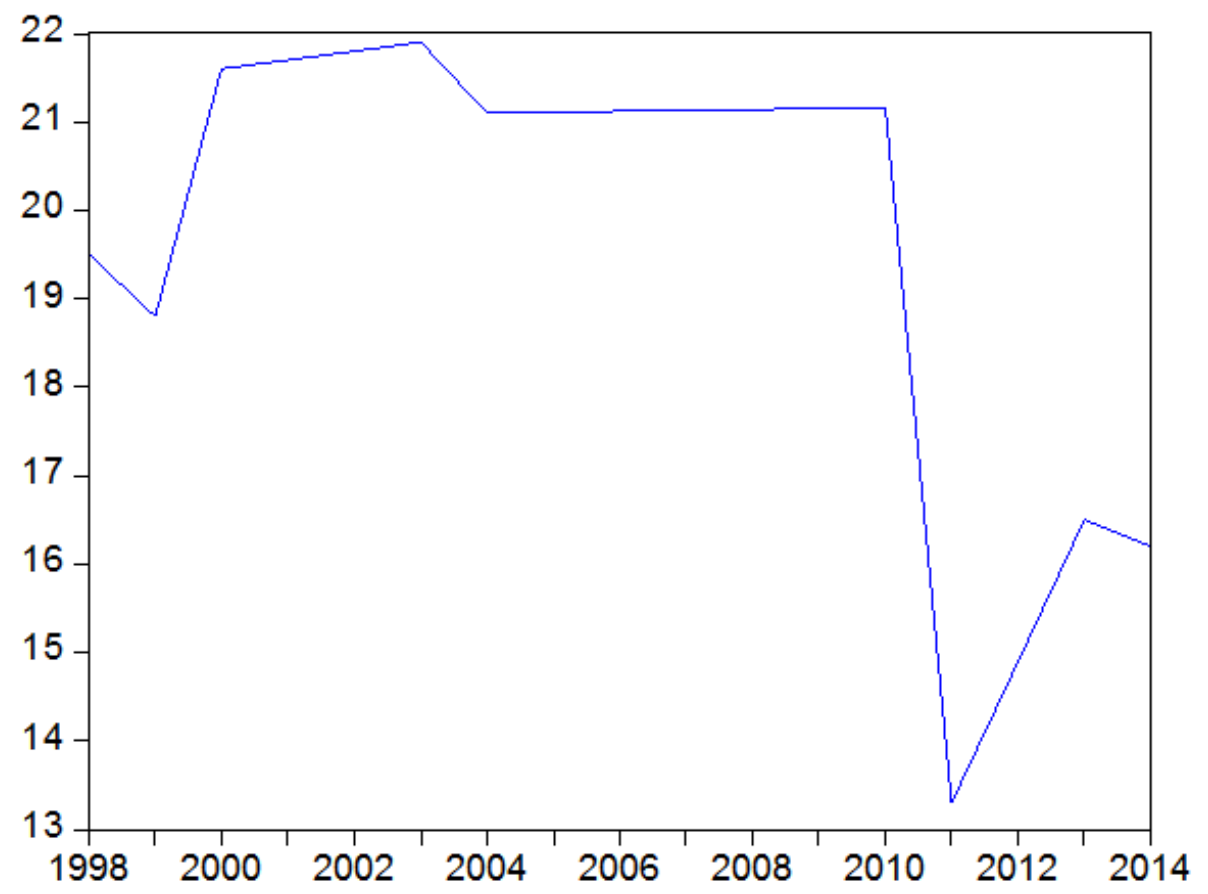

Fig1. Evolution of the ratio of non-performing loans to total loans in Tunisia

The graph below shows the evolution of the ratio of non-performing loans to total loans in Tunisia. We notice that the curve has an upward trend for the period 2011 to 2013. An increasing ratio may be a signal of deterioration in the banking sector results. In theory, we would expect the non-performing loans to total loans ratio to be procyclical within the economic cycle (Alenka K and Mejra F (2010)) 
The Tunisian economy faced in 2011 some difficulties resulting from the political instability in the country, the direct and indirect effects of the conflict in Libya, the difficult social climate, the wait for local and foreign investors, the significant decline of the tourism sector. Indeed, the analysis of the period just before the revolution shows that nonperforming loans are important and stables, then declined in 2011 by 13.3\%. In the period 2011-2014, this indicator grew rapidly from 13,3\% (2011) , 14,9\% (2012), 16,5\% (2013), and 16,2\% (2014) (World Bank). In the wake of a political and social environment, particularly restrictive, the economy marked a slowdown in economic growth since 2011, which causes the increase of the percentage of non-performing loans in the banking sector. A non performing loan is the best indicator measuring systemic risk and economic performance.

During the 2011/2014 period, the nonperforming loans are the main source of systemic risk in the financial and real sector for Tunisia.

\subsection{In Morocco}

Morocco has the most structured financial system of the southern Mediterranean countries, which displays very attractive rate of return. The sector has been reformed since the early 1990s. It is relatively well integrated in the financial and commercial markets (the Maghreb region, the European Union, Sub-Saharan Africa).

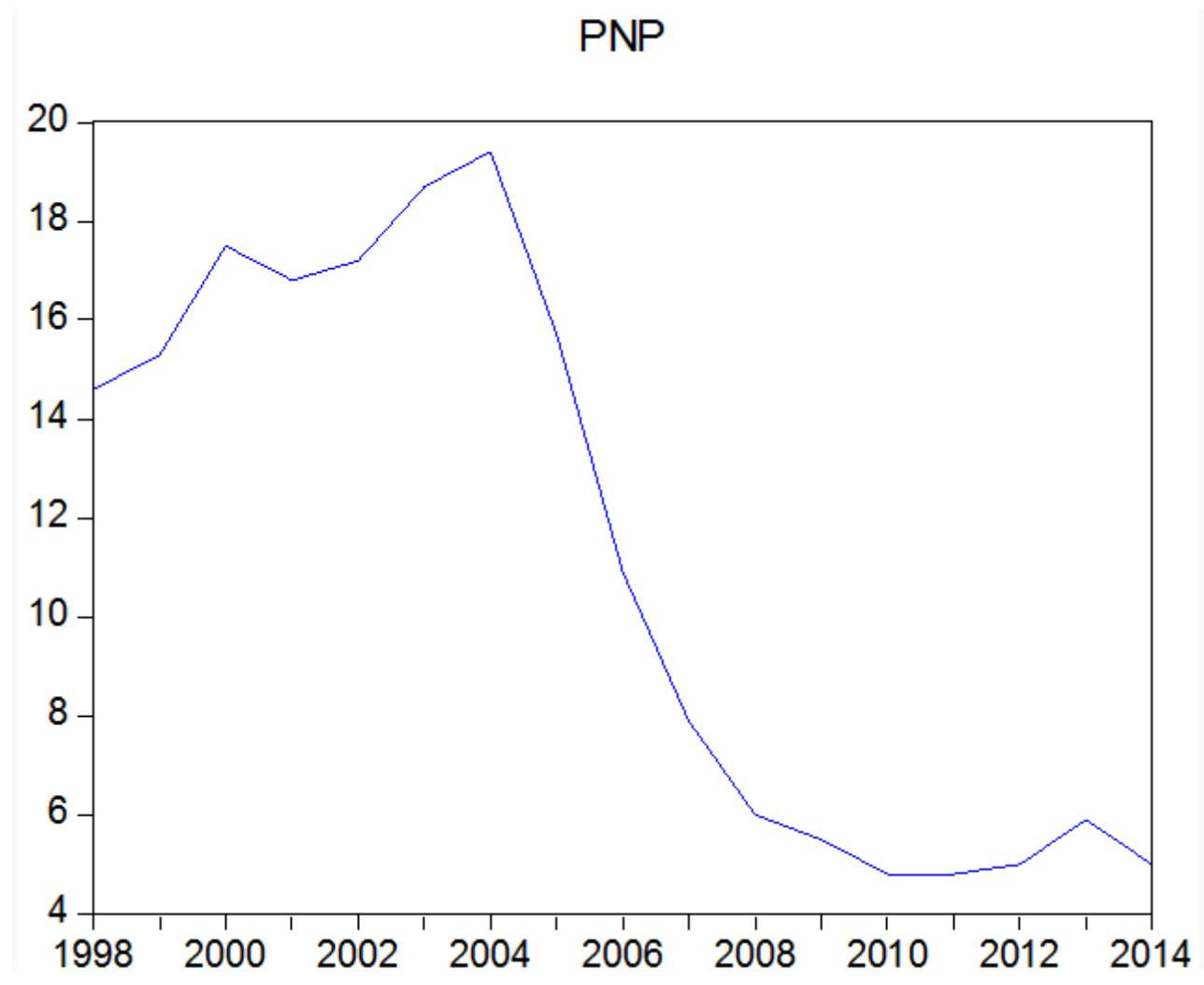

Fig2. Evolution of the ratio of non-performing loans to total loans in Morocco

According to the graph, in Morocco, the nonperforming loans ratio has been declining since 2005 . This result shows that the banking sector for Morocco is in good financial health which reflects a favorable assessment of its economic growth. The Moroccan banking system is healthy, solid, and more profitable in the region.

Morocco has the lowest level of the non-performing loans of the Southern Mediterranean countries and in North Africa, because of the radiation of a large volume of bad loans and the creation of a central risk.

Comparing the NPL ratio of Tunisia with another of the southern Mediterranean countries could be evaluated as a real threat of systemic risk in the financial system. Some countries of the Southern Mediterranean are listed below. 
Table1. Nonperforming loans in total bank loans (\%)

\begin{tabular}{|l|l|l|l|l|l|}
\hline Country /Year & \multicolumn{1}{|c|}{$\mathbf{2 0 1 0}$} & \multicolumn{1}{|c|}{$\mathbf{2 0 1 1}$} & \multicolumn{1}{c|}{$\mathbf{2 0 1 3}$} & \multicolumn{1}{|c|}{$\mathbf{2 0 1 4}$} \\
\hline Tunisia & 13 & 13,3 & 14,9 & 16,5 & 16,2 \\
\hline Morocco & 4,8 & 4,8 & 5 & 5,9 & 6,5 \\
\hline Egypt & 13,6 & 10,9 & 9,8 & 9,3 & 8,9 \\
\hline Lebanon & 4,3 & 3,8 & 3,8 & 4 & 4 \\
\hline Jordan & 8,2 & 8,5 & 7,7 & 7 & 5,6 \\
\hline Turkey & 3,5 & 2,6 & 2,7 & 2,6 & 2,8 \\
\hline
\end{tabular}

Source: World Bank

According to the data in table 2 , we note that the high level of nonperforming loans in 2003 is due to the tourism sector shocks of 2001 impact of which the banking sector continued for a few years later ( FMI 2007). Therefore, the non-performing loans in Tunisia were affected by the tourism sector. At first glance, it is clear that Turkey has the weakest ratio compared to the chosen countries since 2010, whereas Tunisia has the highest nonperforming loans among the Southern Mediterranean countries. Consequently, the situation of Tunisia is better than that of Egypt.

From this table, the Tunisian banking sector is the most exposed to systemic risk caused by the nonperforming loans. The expansion of the level of NPLs and losses incurred by banks on their loan portfolios have shown the interest to understand the determinants of credit risk in order to ensure proper management of this risk and maintain macroeconomic stability and that of financial system ( Hassad $\mathrm{M}$ and al (2010)) . The Tunisian financial systems dominated by the banking sector and play a major role in financing the economy, besides it has been resilient to the effects of the financial crisis and the revolution of 2011. However, recent analyses confirm that the 2011 revolution had an impact on the financial sector (ADB 2012).

According to these data, in Jordan and Turkey, the banks recorded a decline in their non-performing loan ratios. The outlook for the banking sector results possibly reflects a favorable assessment of their economic growth.

\section{THE EMPIRICAL LITERATURE OVERVIEW}

In recent years, the literature examining the non-performing loans (NPL) has attracted the attention of several researchers because of the interest in understanding the factors responsible for the Systemic Risk. A number of studies also consider the relationship between Non-performing loans and systemic risk.

Faward A and Taqodus B (2013) presented the regression of OLS for nine macroeconomic variables : annual growth in GDP, unemployment rates, real interest rates, inflation, the CPI, the real effective exchange rates, exports, industrial production and FDI. They found that GDP growth, interest rates, inflation rates, the CPI, exports and industrial production are significant with non-performing loans. Mejra Festic, Alenka Kaviller, Sebastijan (2011), applied the Panel regression method using the export of goods and services, real GDP, fixed capital formation, FDI, disposable income and compensation of employees, net foreign assets, the ratio of deposit loans, the ratio of asset loans and the basic principles of Bale. The authors studied the macroeconomic sources of systemic risk in the banking sectors of the five new members of the EU. The results indicate that FDI in financial intermediation contributes to the worsening of the non-performing loans. On the other hand, the gross capital formation contributed to the GDP growth and a reduction in bad debts, export growth and industrial production have a direct effect on the sustainability of the results of the banking sector in these countries.

Vlastimir V, Ivana D (2013), compared the domestic banking system of Serbia with some of other countries in transition. They showed that the NPL are the main generator of systemic risk in the financial and real sectors of Serbia. Besides, the Comparative analysis showed similar results not only in the countries in transition, but also in the developed ones. With credit growth, wages, inflation, unemployment and GDP, Carlos Andres (2012), studied the determinants of nonperforming loans in Spain and Italy for the period from Jannuary 2004 to March 2012. This research found that the five independent variables used, only unemplement, wages and GDP are statistitically significant. Roland Beck, Peter Jakubic, et Anamaria Piloiu (2013), studied the macroeconomic determinants of nonperforming loans of 75 countries over ten years on a panel data. In the econometric models used for 
this analysis, the real GDP (measure of macroeconomic performance), the nominal effective exchange rate, the interest rate loans, the stock prices and credit of all the stocks are considered determinants of nonperforming loans. Their econometric analysis suggests that real GDP growth was the main determinant of nonperforming loans. The majority of the studies showed that GDP has a significant impact on NPLs. Therefore; the movement of the real GDP is still the most important factor. Based on methods of dynamic panel data, Dimitrios P and al (2011) concluded that the unemployment rates, the lending rates, the public debt and the GDP have a significant impact on the NPLs.

Alenka Kavkler, Mejra Festic (2010), used monthly data for nine macroeconomic variables ; such as the nominal exchange rate of inflation, the money market interest rate, the gross domestic product, unemployment, the stock exchange index, net export , and loans to private sector as a percentage of GDP, over the period from January 1997 to September 2008 in the case of Romania and Bulgaria. The empirical analysis demonstrated that net exports, the interest rate, and money stock dynamics contributed to an increase in the dynamics of the NPL ratio. According to Beck, Jakubik \& Piloiu (2013), real GDP growth, prices of stocks, exchange rates and interest rates on loans, are macroeconomic determinants of non-performing loans which indicate on the relationship between the NPLs and systemic risk. Other empirical studies have confirmed the linkage between NPLs and macroeconomic environment. For instance, Saoussen O and Sami H (2015) used the data of the Southern Mediterranean Countries over the period of 2000-2012 and employed Panel data to investigate the determinants of nonperforming loans which present the source of systemic risk.

\section{EMPIRICAL ANALYSIS}

\subsection{Data and Methodology}

The existing literature on macroeconomic variables suggests that many macroeconomic variables have strong influence on NPLs .These macroeconomic variables are inflation, interest rate market money, domestic credit to private sector, Public Debt, unemployment rate, exports, annual growth in GDP, exchange rate, Gross Capital Formation. The nine macroeconomic variables are collected from the World Bank data base, over the period 1990-2014.

To compare the macroeconomic sources of systemic risk for Tunisia and Morocco, the model is given as:

$\mathrm{NPL}_{\mathrm{it}}=\alpha_{0}+\alpha 1 \mathrm{INF}_{\mathrm{it}}+\alpha 2 \mathrm{IRMM}_{\mathrm{it}}+\alpha 3 \mathrm{DCPS}_{\mathrm{it}}+\alpha 4 \mathrm{PD}_{\mathrm{it}}+\alpha 5 \mathrm{EXP}_{\mathrm{it}}+\alpha 6 \mathrm{GDP}_{\mathrm{it}}+\alpha 7 \mathrm{NEER}_{\mathrm{it}}+\alpha 8 \mathrm{UR}_{\mathrm{it}}+$ $\alpha 9 \mathrm{GCF}_{\text {it }}+€_{\mathrm{it}}$.

Where;

$\mathrm{NPL}_{\mathrm{it}}$ : is the rate of non-performing loans calculated as percent of the total volume, of loans granted in the respective country $i$ at the moment $t$.

$\mathrm{INF}_{\mathrm{it}}$ : is the inflation rate in the respective country $\mathrm{i}$ at the moment $\mathrm{t}$.

$I_{R M M}$ : is the interest rate market money in the country $i$ at the moment $t$.

$\mathrm{DCP}_{\mathrm{it}}$ : is the domestic credit private sector in the country $\mathrm{i}$ at the moment $\mathrm{t}$.

$\mathrm{PD}_{\mathrm{it}}$ : is the public Debt in the country $i$ at the moment $t$.

$\operatorname{EXP}_{\mathrm{it}}:$ are the exports in the country $\mathrm{i}$ at time $\mathrm{t}$.

GDP $_{\mathrm{it}}$ : is the annual growth rate of Gross Domestic Production the country I at the moment $\mathrm{t}$.

$\mathrm{NEER}_{\mathrm{it}}$ : is the Nominal Exchange Rate in the country i at time t.

$\mathrm{UR}_{\mathrm{it}}$ : is the annual average unemployment rate calculated as a percentage of the total labour force in the respective country $i$ at time $t$.

$\mathrm{GCF}_{\mathrm{it}}$ : is the Gross Capital Formation (\% of GDP) in the respective country i at time $t$.

$€_{\mathrm{it}}$ : stands for the estimation error

$\alpha_{0}, \alpha 1, \alpha 2, \alpha 3, \alpha 4, \alpha 5, \alpha 6, \alpha 7, \alpha 8, \alpha 9$ are the respective coeffcient terms.

The criteria of selecting these variables that empirically exist in the review found positive or negative influence of these variables on NPL and availability of data. 
Saoussen Ouhibi, et al.

Table2. Definition of variables

\begin{tabular}{|c|c|c|c|}
\hline Variables & Definition & $\begin{array}{l}\text { Relation } \\
\text { with NPL }\end{array}$ & Literature \\
\hline INF & $\begin{array}{l}\text { Measured by the consumer price index reflects an } \\
\text { increase in the general price level of goods and } \\
\text { services in an economy over a period of time. }\end{array}$ & $(-)$ & $\begin{array}{l}\text { Faward, A., Taqodus, B. } \\
(2013) \text {, Dash and Kabra } \\
(2010) \text {. }\end{array}$ \\
\hline IRMM & $\begin{array}{l}\text { Interest rate market money is an instrument in money } \\
\text { market can affect the amount of nonperforming loans. }\end{array}$ & $(+)$ & $\begin{array}{l}\text { Alenka Kavkler and } \\
\text { Mejra Festić ( 2010). } \\
\text { Roland Beck, Petr Jakubik } \\
\text { and Anamaria Piloiu } \\
\text { 2013). }\end{array}$ \\
\hline DCPS & $\begin{array}{l}\text { Domestic credit private sector refers to financial } \\
\text { resources provided to the private sector by financial } \\
\text { corporations. }\end{array}$ & $(+)$ & $\begin{array}{l}\text { Alenka K and Mejra F ( } \\
\text { 2010) }\end{array}$ \\
\hline PD & $\begin{array}{l}\text { Public debt is the sum of all domestic and external } \\
\text { obligations of public debtors which include the central } \\
\text { government and its agencies. }\end{array}$ & $(+)$ & $\begin{array}{l}\text { Mehmet I ( 2015), } \\
\text { Carmen R and Kenneth R } \\
\text { ( 2010) }\end{array}$ \\
\hline UR & $\begin{array}{l}\text { The unemployment rate is the ratio between the } \\
\text { number of unemployed and the labor force. }\end{array}$ & $(+)$ & $\begin{array}{l}\text { Saoussen O and Sami H ( } \\
\text { 2015) Jakubík, 2007; }\end{array}$ \\
\hline EXP & $\begin{array}{l}\text { Exports of goods and services can affect the amount of } \\
\text { nonperforming loans. }\end{array}$ & $(-)$ & $\begin{array}{l}\text { Mejra Festic and al( 2011) } \\
\text {, Faward, A., Taqodus, B. } \\
\text { (2013), Babouèek and } \\
\text { Janèar,( 2005) }\end{array}$ \\
\hline GDP & $\begin{array}{l}\text { Annual percentage growth rate of GDP is an } \\
\text { instrument of economic activity. }\end{array}$ & $(-)$ & $\begin{array}{l}\text { Faward, A., Taqodus, B. } \\
\text { (2013), Roland Beck, Petr } \\
\text { Jakubik and Anamaria } \\
\text { Piloiu (2013). }\end{array}$ \\
\hline NEE R & $\begin{array}{l}\text { Nominal effective exchange rate: This rate expresses } \\
\text { the units currency local against the US dollar (USD). }\end{array}$ & $(+)$ & 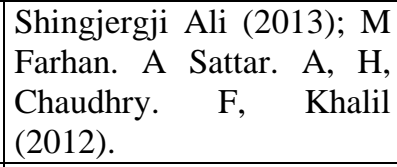 \\
\hline GCF & $\begin{array}{l}\text { Gross capital formation can cause an expansion of bad } \\
\text { loans. }\end{array}$ & $(-)$ & $\begin{array}{lrr}\text { Mejra } & \text { Festic, } & \text { Alenka } \\
\text { Kaviller, } & \text { Sebastijan } \\
(2011) ; & \text { Mejra } & \text { Fistic } \\
(2009) & & \\
\end{array}$ \\
\hline
\end{tabular}

\section{RESUltS AND DiscuSSION}

To explain the macroeconomic sources of systemic risk, we used the OLS regression in a general panel regression model. Thus, most of the existing studies have shown that OLS is an appropriate model to describe the determinants of non-performing loans (Faward A and B Taqodus (2013); Peter Palogh (2012); Shingjergji Ali (2013); SkaricaBruna (2013) Carlos Andres Olaya Bonilla (2012)).

Table3. Panel regression results for Tunisia

\begin{tabular}{|l|l|l|l|l|}
\hline Variables & Co-efficient & Standard Error & T-Statistic & Propability \\
\hline INF & $\mathbf{0 . 2 4 4 9 8 3 1}^{*}$ & 0.49786 & 0.49 & 0.0648 \\
\hline IRMM & -0.317275 & 0.9746895 & -0.33 & 0.761 \\
\hline DCPS & $\mathbf{0 . 2 6 6 9 2 9 3}^{* *}$ & 0.0901229 & -2.96 & 0.041 \\
\hline PD & 0.0488872 & 0.1241477 & 0.39 & 0.714 \\
\hline UR & $\mathbf{1 . 2 3 7 5 8 5}^{* *}$ & 0.4463217 & -2.77 & 0.050 \\
\hline EXP & -0.1809855 & 0.1133384 & -1.60 & 0.532 \\
\hline GDP & $\mathbf{- 0 . 5 2 8 4 1 1}^{*}$ & 0.2866302 & -1.84 & 0.100 \\
\hline NEER & -0.317275 & 0.9746895 & -0.33 & 0.761 \\
\hline GCF & $\mathbf{- 0 . 6 0 7 2 7 0 7}$ & 0.204086 & 2.98 & 0.041 \\
\hline Constant & 49.93397 & 5.39 & 0.006 \\
\hline $\begin{array}{l}\text { R-squared }=0.9744 \\
\text { F statistic }=16.93 \\
\text { Prob ( F-Statistic) }=0.0076\end{array}$ & & & \\
\hline
\end{tabular}

*** Significant at $1 \% \quad ; \quad * *$ Significant at $5 \% \quad ; \quad *$ Significant at $10 \%$ 
There are direct links between the non-performing loans and the macroeconomic variables. The coefficient of determination (R-squared $=0,9744$ ) shows that $97,44 \%$ of the variation in the dependent variable (non-performing loans) can be explained by the model regression.

The table below shows that five macroeconomic variables (Inflation, the domestic credit, gross capital formation, GDP , unemployment rate ) are significant with non-performing loans, while the other variables in our model ( Public Debt, exports, interest rate market money, nominal effective exchange rate ) are insignificant.

In this table, inflation measured by the consumer price index is positive and significant at ten percent level. An increase of ten percent inflation leads to an increase of the NPL ratio by $0.24 \%$. The increase of the general price level negatively affects the real income enabling households to meet their commitments following the increase of the level of inflation (Cadet 2009).

Our results show that credit has a positive and significant impact on the level of nonperforming loans. If the domestic credit grows by 1 percent, the non-performing loans increase by $0,26 \%$. The results of OLS for the domestic credit of the private sector are consistent with the findings of the existing studies of Alenka K and Mejra F (2010) who stated that excess of credit growth to households, which has financed the increasing consumption and led to the deterioration of bad loans, could threaten the stability of the banking sector due to the fact that credit boom-driven deficits are often financed through short-term external debt creation.

According to previous studies, there is a significant negative relationship between nonperforming loans and gross capital formation (Mejra Festic, Alenka Kaviller, Sebastijan (2011); Mejra Fistic (2009)). Similar to these studies, our results mean that the increase in gross capital formation is likely to cause a reduction of nonperforming loan portfolios.

The results in table 2 show statistically significant relationship between the unemployment rate and the nonperforming loans. An increase by one percent of the unemployment rate leads to an increase of the NPL ratio by $1,23 \%$. The results of OLS for growth of the unemployment rate are consistent with the findings existing studies which show positive relationship between the nonperforming loans and the unemployment rate (Saoussen O and Sami H (2015), Jakubík (2007), Louzis et al., 2010) .

The increase of unemployment rate is the main cause of the problems in the banking system and in financial stability in Tunisia. According to Rivlin P (2001), Tunisia has a very high unemployment rate, due to fiscal cuts that are a part of the IMF sponsored stabilization and structural adjustment program, Moreover, there is not enough economic growth to create for jobs for all due to these fiscal cuts. The GDP growth in this country has a negative and significant effect on the nonperforming loans. Table 2 shows that if the GDP increases by 1percent, the non-performing loans decrease by 0 , $52 \%$. It should be noted that this indicator is influenced by the pace of economic activity, while the decline of the economic activity is likely to be caused by the non-payment of loans. Otherwise, the increase in these loans is largely driven by macroeconomic volatility and reflects the vulnerability of the Arab economies. According to DeBock and Demyanets (2012), who assessed the vulnerability of the emerging markets to financial shocks, economic activity slows down when the non-performing loans increase.

Table4. Panel regression results for Morocco

\begin{tabular}{|c|c|c|c|c|}
\hline Variables & Co-efficient & Standard Error & T-Statistic & Propability \\
\hline INF & -0.2517873 & 0.4353752 & -0.58 & 0.594 \\
\hline IRMM & -2.763415 & 1.855839 & -1.49 & 0.211 \\
\hline DCPS & -0.1740396 & 0.2396217 & -0.73 & 0.508 \\
\hline PD & 0.1425272 & 0.2103404 & 0.68 & 0.535 \\
\hline UR & 3.150425 & 1.971045 & 1.60 & 0.185 \\
\hline EXP & -0.1535011 & 0.1829009 & -0.84 & 0.449 \\
\hline GDP & $-0.7254202 *$ & 0.2635708 & 0.29 & 0.0789 \\
\hline NEER & $0.5035602^{* * *}$ & 0.7834877 & -0.64 & 0.055 \\
\hline GCF & 0.1542579 & 0.5616825 & 0.27 & 0.797 \\
\hline Constant & -6.389799 & 17.6277 & -0.36 & 0.735 \\
\hline \multicolumn{5}{|c|}{$\begin{array}{l}\text { R-squared }=0.9885 \\
\text { F statistic }=38.31 \\
\text { Prob(F-Statistic) }=0.0016\end{array}$} \\
\hline
\end{tabular}


The panel regression results for Morocco suggested that only two macroeconomic variables (GDP growth, the nominal effective exchange rate) have a significant correlation with the nonperforming loans. However, for Tunisia, inflation, unemployment rate, domestic credit, and gross capital formation do not appear to be particularly significant in explaining the dynamics on the nonperforming loans for Morocco.

In this country the unemployment rate have a positive but insignificant effect on the nonperforming loans, suggesting that growth in unemployment rate causes the growth of nonperforming loans. The results of this study are similar to the results of the previous studies, including that of Ekanayake $\mathrm{E}$ and Azeez A (2015); Faward A and Taqadus B ( 2013). The unemployment rate reflects the rapid accumulation of impaired loans, and is largely driven by macroeconomic volatility. Regarding the nominal effective exchange rate, we found a significant positive relationship with non performing loans, which suggests that if the exchange rate grows by 5 percent, the non-performing loan's increase by $0,50 \%$. An increase of exchange rate represents an appreciation of the domestic currency. The Currency appreciation can weaken the debt-servicing capabilities of export-oriented firms and thus increase the NPL ratio. Besides, the level of non-performing loan's increases whenever there is a deteriorating international competitiveness of the national economy. This seems to be consistent with the results of Shingjergji Ali (2013); M Farhan. A Sattar. A, H, Chaudhry. F, Khalil (2012).

However, Bruna S (2013) showed that the exchange rate could also positively affect private debtors whose loans are denominated in foreign currency, which can reduce the NPL ratio. The sign of the relationship between NEER and the NPL ratio is thus indeterminate. The results confirmed the influence of the GDP growth, on the dynamics of the nonperforming loans in Tunisia and Morocco, which suggests that Economic Growth is associated with a declining level of the nonperforming loans. Goldstein and Turner (1996) showed that the accumulation of nonperforming loans is generally attributable to a number of factors, including economic downturns and macroeconomic volatility.

\section{CONCLUSION AND IMPLICATIONS}

This research deals with the factors that have an effect on the non-performing loans (systemic risk) in Tunisia and Morocco. The systematic risk factors have a strong impact on all the financial institutions in the market, and the sources of systematic risk are related to the variables that are beyond the bank's control. The situation in Tunisia was particularly more complicated and worse than that of the Morocco, because the proportion of the nonperforming loans increased by $16,2 \%$ in 2014 . This growth, which was the highest in the southern Mediterranean countries, was caused by the Tunisia revolution of 2011. Moreover, the banks are not cautious about providing loans resulted in an increase in non-performing loans (NPLs). These are the most important source of systemic risk in the financial system and the spread of macroeconomic contagion. In this situation, the empirical results show that the Inflation, domestic credit, gross capital formation, GDP and unemployment rate are significant with the nonperforming loans in Tunisia. However, in Morocco, only the exchange rate and GDP are significant.

The analysis of the Tunisian macroeconomic indicators has proven the tight dependency of the nonperforming loans on the changes of the economic environment in the country.

The increase of the unemployment rate, the domestic credit, inflation and the gross capital formation highly increased the percentage of NPLs. However, the increase of GDP and the gross capital formation can decrease the percentage of the nonperforming loans. The analysis of the Moroccan macroeconomic indicators related to the exchange rate and GDP growth may be considered as very important determinants of systemic risk.

The main policy implications arising from our study can be presented as follows: first, evidence showed that the banking system of the southern Mediterranean countries reveals a correlation between economic trends and the nonperforming loans. Therefore, it is necessary to look for other macroeconomic determinants to assess systemic risk in the financial system. The resolution of the source of the systemic risk in the southern Mediterranean countries represents a challenge since the financial system for these countries is complex and poorly developed. Secondly, based on the increased risk of the high proportion of the nonperforming loans in the banking sector, it is necessary to introduce reforms in the banking liberalization, such as the macroprudential tools. Besides, it is important for policy makers to implement sound economic policies which can lead to the reduction of systemic risk and achieve financial stability. These reforms improve the efficiency of the economy and strengthen the aspects of supply in the economy. 


\section{REFERENCES}

ADB (2012), "Tunisia: Economic and Social Challenges Beyond the Revolution», African Development Bank Group.

Alenka, K., Mejra, F. (2010), « The trade deficit and banking sector results in Romania and Bulgaria », Economic Interferences, Vol XII No. 27, February 2010.

Beck, R., Jakubik, P., Piloiu, A. (2013), « Non-performing loans: what matters in addition to the economic cycle?». Working papers 1515/2013. European Central Bank.

Carlos, A., Olaya, B. (2012), «Macroeconomic determinants of the Non-Performing Loans in Spain and Italy », Department of Economics University of Leicester.

Carmen, R., Kenneth, R. (2010), «From Financial Crash to Debt Crisis », American Economic Review: 1676-1706.

Dimitrios, P. L., Angelos, T.V., Vasilios, L.M. (2011), " Macroeco-nomic and bank-specific determinants of non-performing loans in Greece: A comparative study of mortgage, business and consumer loan portfolios », Journal of Banking and Finance.

Faward, A., Taqodus, B. (2013), « Explanatory Power of Bank Specific Variables as Determinants of Non-Performing Loans: Evidence form Pakistan Banking Sector », World Applied Sciences Journal, Vol .22, No.9, pp. 1220-1231.

Hassad, M ., El Ghak, T. ( 2010), «Credit risk through the cycles of activity : an analysis on a panel of Tunisian banks of deposit», revue libanaise de gestion et d'économie , volume 4, Issue 6 , pages $1-20$.

Hippolyte, F . (2005), « nonperforming loans in Sub - Saharan Africa: Causal Analysis and macroeconomic Implications, World Bank Policy Research Working Paper 3769 .

Mehmet ,I. (2015), «The Effect of Macroeconomic variables on Non-performing Loan Ratio of Publicly Traded Banks in Turkey».Wseas Transactions on Transactions on Business and Economics.

Mejra ,F., Alenka ,Kaviller, Sebastijan . (2011), « The macroeconomic sources of systemic risk in the banking sectors of five new EU ». Journal of Banking and Finance, pp 310-322.

Roland, B., Petr, J., Anamaria, P. ( 2013), « Non-performing loans What matters in addition to the economic cycle?». Working Paper SerieS NO 1515.

Vlastimir V, Ivana D (2013), « Non-performing Loans and Systemic Risk: Comparative Analysis of Serbia and Countries in Transition CESEE », Original Scientific Paper, Vol.41, No.4, 2013. 